\title{
HISTOPATOLOGI JANTUNG TIKUS PADA TOKSISITAS SUB KRONIS EKSTRAK ETANOL 70\% KULIT BUAH JERUK Citrus nobilis Lour.
} (Histopathology Heart Rat of Sub Chronic Toxicity 70\% Ethanol Extract
Citrus nobilis Lour. Peel)

\author{
Farizah Izazi $^{1}$, Bambang Prayogo ${ }^{2}$, Eka Pramyrtha Hestianah ${ }^{3}$, Endri Zulkarnain ${ }^{2}$ \\ ${ }^{1}$ Prodi Farmasi Fakultas Kedokteran Universitas Hang Tuah, Surabaya, Indonesia \\ ${ }^{2}$ Fakultas Farmasi, Universitas Airlangga, Surabaya, Indonesia \\ ${ }^{3}$ Fakultas Kedokteran Hewan, Universitas Airlangga, Surabaya, Indonesia \\ Email:Farizah.Izazi@hangtuah.ac.id
}

\begin{abstract}
This research aimed to study the histopathological heart rat of sub chronic toxicity $70 \%$ ethanol extract Citrus nobilis Lourr. Peel. This study used 40 male white Galur Wistar rats in sub-chronic toxicity and each divided into 4 groups (control group giving CMC $\mathrm{Na}$ 0,5\%, dose group $40 \mathrm{mg} / \mathrm{kg} \mathrm{BB}$, dose group $200 \mathrm{mg} / \mathrm{kg} \mathrm{BB}$, and dose group $1000 \mathrm{mg} / \mathrm{kb} \mathrm{BB})$. Each group consists of $10 \mathrm{males}$. Each cage contains 5 rats of the same age and gender, fed and drunk in ad libitum method. Furthermore, the rats are being weighing in. $70 \%$ extraction of Citrus nobilis Lour peel is orally given to the rats, every day for 90 days accordance with the group. After rats were given dose treatment for 90 days then observed histopathology of heart. Each rat organ preparation was observed in five different fields of view then scored and processed with rank ratings then analyzed using non parametric statistical test using Kruskal Wallis test. $70 \%$ extraction of Citrus nobilis Lour peel for 90 days with a dose of 1000mg / $\mathrm{kg}$ of rats based on statistical tests showed damaged heart muscle cell on histopathological observation of the heart. It is then expected to continue on the chronic toxicity test of $70 \%$ extraction of Citrus nobilis Lour peel for 12 months to predict the safety of clinical use in humans in the long term.
\end{abstract}

Key word: heart, Citrus nobilis Lour.of peel, sub chronic toxicity

\section{PENDAHULUAN}

Citrus nobilis Lour. merupakan tanaman jeruk yang banyak digemari di Indonesia sehingga penyebarannya di Indonesia cukup banyak. Tingginya tingkat konsumsi buah jeruk ini mengakibatkan limbah yang tidak terpakai seperti halnya kulit buah Citrus nobilis Lour.yang semakin banyak menumpuk dan terbuang sia-sia karena dianggap tidak bermanfaat. Pada penelitian ini menggunakan kulit buah jeruk yang berasal dari daerah Tanggul - Padang Rejo, Jember. Dalam kulit buah Citrus nobilis Lour. mengandung berbagai macam komponen yaitu vitamin $\mathrm{A}$, vitamin $\mathrm{B}$, vitamin $\mathrm{C}$, hesperidin, limonene, citral dan metyl antranilate (Li, 2002).

Hesperidin merupakan senyawa glikosida flavonoid dan senyawa polifenol yang termasuk senyawa inhibitor hialuronidase (Prajogo $d k k$, 1997). Banyaknya penelitian terkait dengan adanya hesperidin sebagai penghambat enzim hialuronidase. Berdasarkan hal tersebut, maka kulit buah jeruk keprok atau Citrus nobilis yang sebelumnya dianggap tidak bermanfaat dapat dijadikan alternatif sebagai bahan obat KB pada pria di mana akan dikembangkan menjadi obat herbal terstandar (OHT).

BPOM mempersyaratkan untuk pengembangan obat tradisional menjadi obat herbal terstandar (OHT) harus melalui prekilinik dan uji klinik untuk menjamin khasiat dan keamanan sediaan. Uji preklinik dilakukan untuk menjamin keamanan sediaan, yaitu dengan melakukan uji toksisitas. Uji toksisitas untuk mengetahui derajat bahaya suatu sediaan uji apabila terjadi pemaparan sediaan uji pada waktu singkat maupun secara berulang dalam jangka waktu tertentu, sehingga dapat ditentukan dosis penggunaannya demi keamanan penggunaan obat pada manusia (BPOM, 2014). Dalam uji preklinik yang dilakukan adalah salah satunya uji toksisitas sub kronis.

\section{II.TINJAUAN PUSTAKA}

Uji toksisitas adalah suatu uji untuk mendeteksi efek toksik suatu zat pada sistem biologi. Selain itu juga digunakan untuk 
memperoleh data dosis-respon yang khas dari sediaan uji. Data yang diperoleh dapat digunakan untuk memberi informasi mengenai derajat bahaya sediaan uji tersebut bila terjadi pemaparan pada manusia, sehingga dapat ditentukan dosis penggunaannya demi keamanan manusia. (BPOM, 2014).

Uji toksisitas memiliki beberapa manfaat. Manfaat yang dapat diperoleh dari studi toksisitas tersebut antara lain adalah untuk mendapatkan gejala-gejala yang timbul akibat pemberian obat, mengetahui batas keamanan obat, dan untuk mengetahui derajat kematian hewan coba akibat pemberian obat (Ghosh, 1971; Loomis, 1978).

Toksisitas sub kronis antara lain digunakan untuk memperoleh informasi adanya efek toksik zat yang tidak terdeteksi pada uji toksisitas akut, informasi kemungkinan adanya efek toksik setelah pemaparan sediaan uji secara berulang dalam jangka waktu tertentu, informasi dosis yang tidak menimbulkan efek toksik (No Observed Adverse Effect Level I NOAEL) dan mempelajari adanya efek kumulatif dan efek reversibilitas zat tersebut (BPOM, 2014).

Diketahui bahwa kulit buah Citrus nobilis Lour salah satunya mengandung hesperidin. Hesperidin merupakan senyawa golongan flavonoid yang termasuk glikosida flavanon, terdiri dari heperitin sebagai flavanon serta rutinose sebagai disakarida. Rutinose terdiri dari gula rhamnoe (6-deoy-L-mannose) dan glukosa. Hesperidin adalah flavonoid yang banyak terdapat pada jeruk dan lemon, dimana pada kulitnya ditemukan konsentrasi hesperidin terbanyak. Menurut Gyorgy dan szent (2000) hesperidin adalah suatu bioflavonoid yang merupakan bagian dari suatu kelompok zat berwarna yang ditemukan pada banyak buahbuah seperti citrin serta dalam kulit buah.

Beberapa penelitian telah dilakukan untuk mengetahui aktivitas Citrus nobilis Lour sebagai antifertilitas. Mekanisme utamanya adalah melalui hambatan enzim hialuronidase spermatozoa yang bersifat kompetitif dan reversibel. Enzim hialuronidase merupakan enzim yang terdapat pada bagian kepala (akrosom) spermatozoa (Gilbert, 1988). Seperti telah diketahui, sel telur mempunyai 3 lapisan, yaitu kumulus oofurus, korona radiata, dan zona pelusida.

Fertilisasi dapat terjadi jika spermatozoa dapat menembus ketiga lapisan tersebut. Enzim hialuronidase berfungsi untuk penetrasi spermatozoa pada cumulus oophorus, Corona Penetration Enzym pada korona radiata, akrosin pada zona pelusida. Ketiga enzim ini bekerja secara spesifik dan berurutan. Apabila aktivitas enzim hialuronidase dihambat, maka penetrasi spermatozoa tidak terjadi dan begitu juga pada proses fertilisasi (Zaneveld, 1976).

Berdasarkan data penelitian yang telah dilakukan pada uji klinik hesperidin terfosforilasi pada 300 pasangan dalam bentuk tablet dosis $100 \mathrm{mg} / \mathrm{kg}$ BB setiap harinya hasilnya dapat mencegah fertilisasi invitro mencit pada dosis hesperidin 2, 4 dan $6 \mathrm{mg} / 20$ g BB peroral serta hesperidin dosis 25,50 dan 100 ppm dapat menurunkan daya disperse cumulus oophurus secara invitro (Scarpe, 1997). Selain itu hesperidin dosis 100, 200, dan $300 \mathrm{mg} / \mathrm{kg}$ BB secara peroral dapat menurunkan aktivitas hialuronidase spermatozoa mencit. Hesperidin, rutin, apigenin, kuersetin dan asam tanat juga diketahui dapat mencegah pentrasi spermatozoa sel telur pada fertilisasi invitro mencit dan kera ( $\mathrm{Li}$ et al., 1997). Pada penelitian sebelumnya diketahui bahwa pada dosis hesperidin 2,4 dan $6 \mathrm{mg} / 20 \mathrm{~g} \mathrm{BB}$ mencit dapat mencegah penetrasi spermatozoa dalam fertilisasi in vitro (Prajogo et al., 1997). Hal ini berarti bahwa kulit buah Citrus nobilis Lour. dapat dijadikan alternatif alat kontrasepsi yang poten.

Oleh karena hal tersebut yang mendasari penelitian ini, untuk dapat dikembangkan menjadi bahan obat maka sebelumnya dilakukan uji toksisitas. Salah satu uji toksisitas yaitu toksisitas subkronis. Uji toksisitas sub kronis dilakukan untuk melihat tingkat keamanan dari ekstrak etanol $70 \%$ kulit buah Citrus nobilis lour. Dalam hal ini melihat histopatolgi jantung dari tikus.

\section{III.METODE PENELITIAN}

Penelitian ini dilakukan Laboratorium Departemen Farmakognosi dan Fitokimia Fakultas Farmasi Universitas Airlangga Surabaya serta pemerikasaan Histopatologi Dilakukan di Laboratorium Patologi Veteriner Fakultas Kedokteran Hewan Universitas Airlangga Surabaya. Penelitian dilakukan selama 90 hari. Pada penelitian ini menggunakan tikus jantan dengan berat badan 150-300 gram dan umur 6-8 minggu yang diperoleh dari Lab Biokimia FK Unair. Variasi 
berat badan tidak melebihi $20 \%$ dari rata-rata berat badan.

\subsection{Alat dan Bahan}

Alat yang digunakan dalam penelitian ini antara lain timbangan analitik, timbangan untuk hewan coba, kandang plastik dengan kawat penutup, sonde lambung, pinset, alat bedah, mikroskop cahaya dengan digital camera DS Fi2.

Bahan uji yang digunakan adalah kulit buah Citrus nobilis Lour. Citrus nobilis Lour yang digunakan berasal dari daerah tanggul padang rejo umbul sari Jember yang di panen pada usia 4 bulan dan telah diidentifikasi Lembaga Ilmu Pengetahuan Indonesia UPT Balai Konservasi Tumbuhan Kebun Raya Purwodadi. Kulit yang bersih dikeringkan dengan cara diangin-anginkan, setelah kering dibuat serbuk. Serbuk kering kemudian diekstraksi dengan pelarut etanol $70 \%$, sehingga diperoleh ekstrak etanol $70 \%$ kulit buah Citrus nobilis Lour.

\subsection{Prosedur Penelitian Penyiapan hewan coba}

Tikus jantan diadaptasikan dengan lingkungan selama 1 minggu. Semua tikus dipelihara dengan cara yang sama dan mendapat diet yang sama pula. Sebelum dilakukan perlakuan, semua tikus ditimbang untuk menghitung pengaturan dosis. Tikus dikelompokkan secara acak sedemikian rupa sehingga penyebaran berat badan merata untuk semua kelompok dengan variasi berat badan tidak melebihi $20 \%$ dari rata-rata berat badan. Berat badan tikus diukur sebelum perlakuan, selama perlakuan, dan setelah perlakuan. Monitoring kenaikan berat badan dilakukan seminggu dua kali.

\section{Penyiapan Bahan Uji}

Pemberian tiap dosis dalam bentuk ekstrak yang disuspensikan dalam musilago $\mathrm{CMC} \mathrm{Na} 0,5 \%$. Kontrol negatif diberi musilago CMC Na $0,5 \%$

\subsection{Uji Toksisitas Sub Kronis}

Berdasarkan OECD disiapkan 4 kelompok tikus yang masing-masing kelompok terdiri dari 10 ekor tikus. Pemberian dilakukan secara per oral (dengan volume pemberian maksimal 1-2 $\mathrm{mL}$ sediaan uji/ $100 \mathrm{~g}$ BB hewan), satu kali sehari selama 90 hari. Selama 90 hari. Hewan ditimbang setiap hari untuk menentukan volume sediaan uji yang akan diberikan.

- Kelompok kontrol : sebagai kelompok kontrol, diberi CMC Na 0,5\%

- Kelompok 1: diberi ekstrak etanol 70\% kulit buah Citrus nobilis Lour dengan dosis $40 \mathrm{mg} / \mathrm{kg} \mathrm{BB}$

- Kelompok 2: diberi ekstrak etanol 70\% kulit buah Citrus nobilis Lour dengan dosis $200 \mathrm{mg} / \mathrm{kg} \mathrm{BB}$

- Kelompok 3: diberi ekstrak etanol 70\% kulit buah Citrus nobilis Lour dengan dosis $1000 \mathrm{mg} / \mathrm{kg} \mathrm{BB}$

\subsection{Pembuatan Preparat Histopatologi}

\section{- Fiksasi}

Jantung direndam didalam larutan dapar formalin $10 \%$ segera setelah pengambilan organ dan direndam selama 24 jam. Kemudian dilakukan pencucian dengan air kran.

- Pemotongan blok parafin dengan mikroton

Siapkan mikroton, dilakukan pemotongan dengan ketebalan 4-7 m. Kemudian dicelupkan pada air suhu $20^{\circ} \mathrm{C}$ agar jaringan mengembang dengan baik. Setelah itu diletakan pada gelas objek sebelum diolesi dengan egg albumin lalu dikeringkan dengan hot plate agar organ dan menempel pada gelas objek.

- Pewarnaan Jaringan dengan Hematoxylin Eosin

Proses perwarnaan dilakukan dengan memasukkan irisan jaringan yang terletak pada gelas objek ke dalam reagen. dan dicuci dengan air mengalir selama 5 menit. Kemudain jaringan direndam dalam Hematoxylin selama 10 menit, lalu dicuci dengan air mengalir selama 10 menit. Selanjutnya direndam dalam eosin selama 3-5 menit, dilanjutkan denagn peredaman dalam etanol.

- Dehidrasi dan Clearing

Dilakukan dehidrasi etanol 70\%, 80\%, 90\% (2 kali). Kemudian dilakukan clearing dengan Xylen (3-4 kali).

- Lapisan Kanada balsam dan Penutupan Pemberian lapisan kanada balsam pada gelas objek yang telah diwarnai dan kemudian ditutup dengan cover glass.

\subsection{Pemeriksaan Preparat Histopatologi}

Digunakan mikroskop cahaya untuk mengamati secara mikroskopik preparat organ 
tikus. Mula-mula digunakan perbesaran 100 kali kemudian digunakan perbesaran 400 kali. Setiap preparat organ tikus diamati perubahannya melalui lima lapang pandang yang berbeda, yang diamati adalah:

Degenerasi sel: terdapat perubahan pada sitoplasma sel berupa pembengkakan, akumulasi air, atau lemak

- Pendarahan: terdapat akumulasi eritrosit di luar pembuluh darah

- Nekrosis sel: terdapat perubahan pada inti sel berupa penggumpalan, reksis, atau lisis.

Adapun cara penilaian berupa penentuan skor (Robert klopfeisch, 2013) yaitu:

1. Nilai 0: Normal (kerusakan 0\%)

2. Nilai 1: Kerusakan ringan (>0\%-25\%)

3. Nilai 2: Kerusakan ringan (>25\%-50\%)

4. Nilai 3: Kerusakan ringan (>50\%-75\% atau lebih)

\section{HASIL DAN PEMBAHASAN}

\section{Pemeriksaan Histopatologi Jantung Tikus}
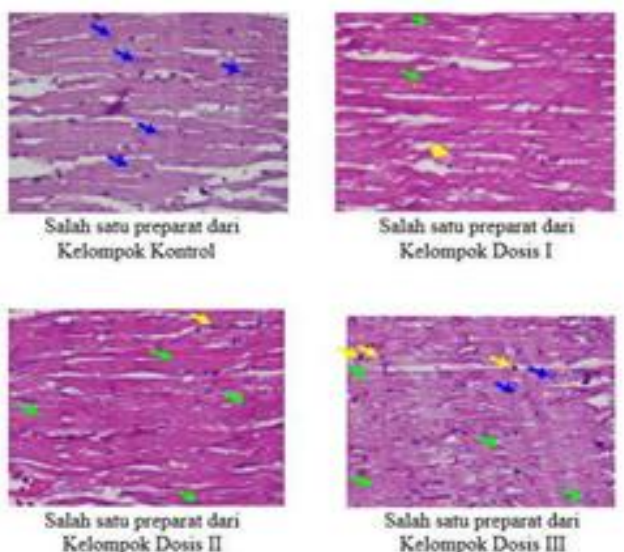

Gambar 4.1 Gambaran histopatologi jantung dengan pewarnaan HE pada perbesaran 400x

Keterangan :

Panah Biru (Sel Normal)

Panah Hijau (Nekrosis)

Panah Kuning (Sel Radang)

Tabel 4.1. Hasil pengamatan kerusakan sel otot jantung

\begin{tabular}{|l|l|}
\hline Kelompok & $\begin{array}{l}\text { Rata-rata Nekrosis } \\
\text { Sel otot jantung }\end{array}$ \\
\hline Kontrol & $0.20^{\mathrm{a}} \pm 0.05$ \\
\hline Dosis 1 & $0.30^{\mathrm{a}} \pm 0.03$ \\
\hline Dosis 2 & $0.62^{\mathrm{b}} \pm 0.03^{*}$ \\
\hline Dosis 3 & $1.50^{\mathrm{b}} \pm 0.04^{*}$ \\
\hline
\end{tabular}

Keterangan :

Huruf superscript yang berbeda menyatakan adanya perbedaan yang signifikan $(\mathrm{p}<0.05)$ antar kelompok

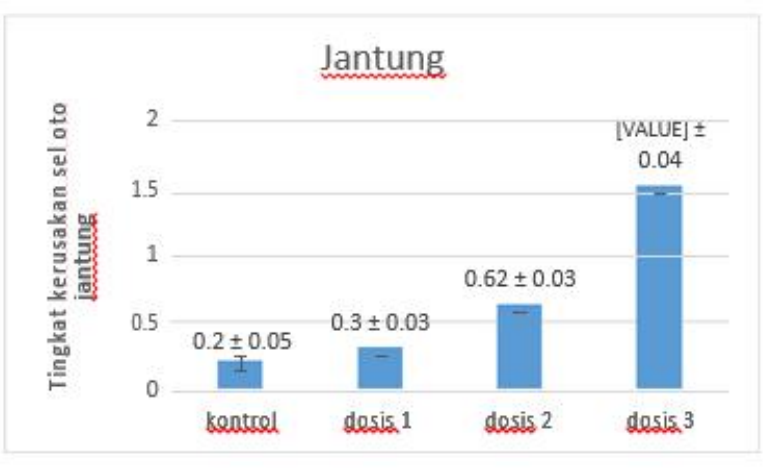

Gambar 4.2 Hasil Uji Tingkat Kerusakan Sel otot Jantung

Hasil uji Kruskal Wallis didapatkan nilai p-value sebesar 0.000. Jika nilai p-value kurang dari batas kritis atau 5\% maka tolak $\mathrm{H}_{0}$ artinya pemberian ekstrak etanol $70 \%$ kulit buah Citrus nobilis Lour memberikan pengaruh yang signifikan terhadap kerusakan sel otot jantung tikus. Dikarenakan hasil uji Kruskal Wallis menunjukan adanya perbedaan yang signifikan maka dilajutkan dengan uji U Mann Whitney. Hasil uji U Mann Whitney sebagai berikut.

- Kontrol dengan dosis I

Didapatkan nilai signifikan sebesar 0.579 artinya $\mathrm{H}_{0}$ diterima karena $\mathrm{p}$-value lebih dari $5 \%$, tidak ada perbedaan bermakna kerusakan sel antara kelompok kontrol dengan dosis I. Dapat disimpulkan ekstrak etanol $70 \%$ kulit buah Citrus nobilis Lour pada dosis I (40mg/Kg BB tikus) tidak mempengaruhi kerusakan sel otot jantung.

Kontrol dengan dosis II

Didapatkan nilai signifikan sebesar 0,000 artinya $\mathrm{H}_{0}$ diterma karena p-value kurang dari $5 \%$, tidak ada perbedaan bermakna t kerusakan sel otot jantung antara kelompok kontrol dengan dosis II. Dapat disimpulkan ekstrak etanol $70 \%$ kulit buah Citrus nobilis Lour pada dosis I (200mg/Kg BB tikus) tidak mempengaruhi tingkat kerusakan sel otot jantung.

- Kontrol dengan dosis III 
Didapatkan nilai signifikan sebesar 0.000 artinya tolak $\mathrm{H}_{0}$ karena p-value kurang dari $5 \%$, ada perbedaan bermakna kerusakan sel otot jantung antara kelompok kontrol dengan dosis III. Dapat disimpulkan ekstrak etanol 70 $\%$ kulit buah Citrus nobilis Lour pada dosis II (1000mg/Kg BB tikus) mempengaruhi kerusakan nekrosis sel otot jantung dalam hal ini ekstrak etanol $70 \%$ kulit buah Citrus nobilis Lour mampu mempengaruhi kerusakan sel otot jantung.

Nekrosis merupakan kematian sel atau jaringan pada organisme hidup. Nekrosis adalah proses patologis setelah terjadinya cedera sel. Nekrosis banyak penyebabnya, tergantung jenis jaringan dan penyebabnya. Perubahan degenerasi juga bisa menyebabkan nekrosis pada keadaan tertentu, seperti penyebab cedera yang tetap pada perubahan hidropik dan perubahan lemak yang berat (underwood, 1996). Terjadinya perubahan degenerasi yang lama juga bisa menyebabkan sel tidak mampu mengkompensasi perubahan yang bisa menyebabkan nekrosis (Price dan Wilson, 1992).

Dari hasil data diatas di ketahui bahwa pada dosis I, dosis II, dan dosis III dengan tingkat kerusakan jantung kurang dari 25\% hingga lebih dari $25 \%$ sampai $50 \%$. Pada dosis III $1000 \mathrm{mg} / \mathrm{kg}$ BB pemberian ekstrak etanol $70 \%$ kulit buah Citrus nobilis Lour. mempengaruhi tingkat kerusakan sel otot jantung. Oleh karenanya untuk penggunaan ekstrak etanol $70 \%$ kulit buah Citrus nobilis Lour. sebaiknya digunakan pada dosis dibawah $1000 \mathrm{mg} / \mathrm{kg} \mathrm{BB}$.

\section{PENUTUP}

Pada pemberian ekstrak etanol $70 \%$ kulit buah Citrus nobilis Lour selama 90 hari dengan dosis $1000 \mathrm{mg} / \mathrm{Kg}$ BB pada tikus berdasarkan uji statistik mempengaruhi tingkat kerusakan sel otot jantung pada pengamatan histopatologi jantung, sehingga diharapkan penelitian selanjutnya dapat dilakukan uji toksisitas kronik ekstrak etanol $70 \%$ Kulit buah Citrus nobilis Lour selama 12 bulan untuk memprediksi keamanan penggunaan klinik pada manusia dalam jangka panjang.

\section{DAFTAR PUSTAKA}

[1] BPOM RI. (2014). Peraturan Kepala Badan Pengawas Obat dan Makanan RI No. 7 Tahun 2014 tentang Pedoman Uji Toksisitas Nonklinik secara In Vivo

[2] Ghosh, M.N. (1971). Fundamentalof Eksperimental Pharmacology. Scientific Book Agency, Calcutta. Pp 84-90.

[3] Gyorgy and Szent, A. (2000). Hespiridin from Citrus spp.

http://www.symmcorp.com/info/hespiridin/htm 1. 1 Desember 2005.

[4] Li, M,W., Al., Yudin, V., Voort, K., Sabeur, P., Primakoff, and J.W. (1997). Inhibition of Monkey Sperm Hyaluronidase Activity and Heterologous Cumulus Penetration by Flavonoid In: Biol. Reprod., 56:6, p. 1383-1389.

[5] Li, T.S.C. (2002). Chinese related North American Herbs Phytopharmacology and Therapeutics Value. Boca Raton: CRC Press [6] Loomis, T. (1978). Essential of Toxicology, $\quad 3^{\text {rd }}$ Edition. Philadelphia: Lea \& Febriger. P 22.

[7] Prajogo, B.E.W, Widjiati, Hamdanidan Aucky, $\quad \mathrm{H}$.

Hambatan hesperidin terhadap penetrasi spermatozoa mencit dalam proses fertilisasi in vitro, Simposium Penelitian Bahan Obat Alami IX, Yogayakarta.

[8] Zaneveld, L.J.D. (1976). Sperm Enzyme Inhibitor andAntifertility Agents In: Human Semen and Fertility Regulation in Men. E.S.E., Hafez (ed), London CV. Mosby Company, St. Louis., p. 576-578 